することの有効性と効率化について報告があった。

一般講演の 3 件は日本の大学関係者による講演であった が， 2 件は海外からの留学生による講演であり，また 1 件 は韓国の大学との共同研究, 1 件は夕イの大学および企業 との共同研究に関する講演であり，アジアワークショップ に相応しい講演であった. 北陸先端科学技術大学のグルー プからは移行現象を利用した高分子表面へのカーボンナノ チューブの局在化に関する研究報告, 徳島大学のグループ
からは竹/PBS 複合材料の静的および動的特性に及ぼす繊 維長の影響について, 京都工芸繊維大学のグループからは ナノサイズのゴムを添加したポリプロピレン複合材料の力 学的特性および結晶化挙動について報告があった。

本セッションが行われた Sakura Room は比較的小さめ の部屋で, 議論がしやすかったためか, 活発な質疑応答, 討議をおこなうことができ有意義であった.

\title{
AWPP 2010 報告 Poster Presentation, Technical Tour
}

ポスターセッションは, 学会二日目（12月 8 日）の 17 : 50-18：50に行われた. ポスター会場は, バンケット会場 である Tao Li レストラン前のロビーで開催された。ポス ター発表の件数は 52 件であり, その内訳は『Alloys, Blends \& Composites』セッション 10 件, 『Nano Technology』セッ ション 8 件, 『Structure, Properties \& Their Evaluation』 セッション 7 件, 『Polymer Modification \& Novel Materials』セッション 7 件, 『Rheology \& Rheometry』セッショ ン 3 件, 『Extrusion \& Injection Moulding』セッション 2 件, 『Fiber Spinning \& Film』セッション 2 件, 『Biopolymer \& Process Optimization』セッション 1 件, 『Emerging Polymer Processing Technologies』セッション 1 件, そ の他 11 件であった. オーラルセッションの直後であった が，どのポスターにも人が集まっており，疲れを微鹿も感 じさせない活発な議論が行われていた．ポスター賞受賞者 はバンケットで発表され, 日本側委員長である横井先生よ り表彰状と記念品が手渡された. 図 1 にバンケットでの授 賞式の様子を示す.

テクニカルッアーは, 学会三日目 (9日) 午後および最 終日（10日）に開催された。9日はハノイ市郊外にある Honda Vietnam Co., Ltd. の二輪車工場を見学した. ベト ナムの主要な交通手段である二輪車を年間 200 万台製造し ているラインでは, 手作業で一つ一つの部品を組み立てて いるところが印象的であった。 10 日の午前中はハノイ市 郊外にある Garco 10 の縫製工場を見学した. Garco 10 の ロゴマークに記載されている『May』はベトナム語で『textile』を意味しているとのことであった，日本の大手紳士 服販売店にも出荷しているこの工場では, 作業員が各パー ツを正確且つ迅速に縫い合わせているところが印象的で あった. Garco 10 を後にした参加者は，バスに約二時間 摇られた後ハロン湾を見学した。 ハロン湾は，世界遺産に 登録されているべトナムで最も有名な景勝地である. 八ロ ンとは『龍が降りた場所』という意味であり,この地に降

\footnotetext{
* Yamamoto, Yoshimasa

長岡技術科学大学 工学部 物質 - 材料系

長岡市上富岡町 1603-1（广940-2188）

2011.2.28 受理
}

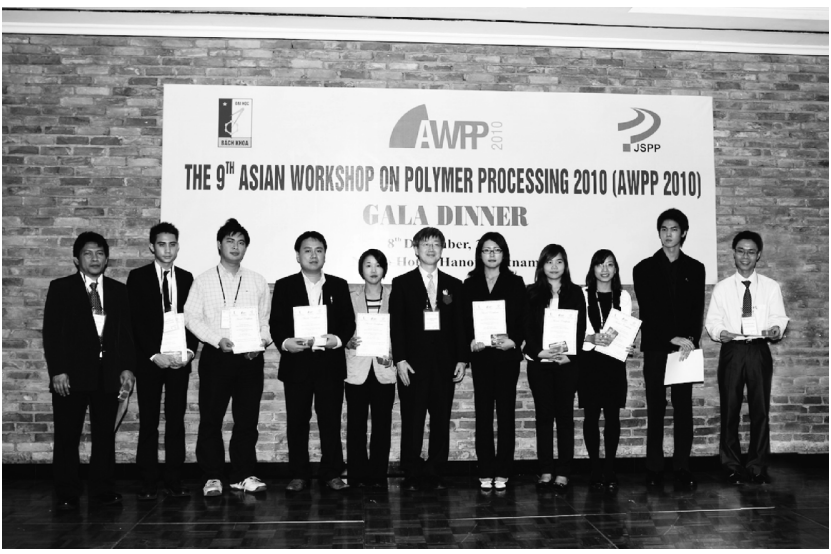

図 1 ポスター発表賞授賞者（授賞式にて）

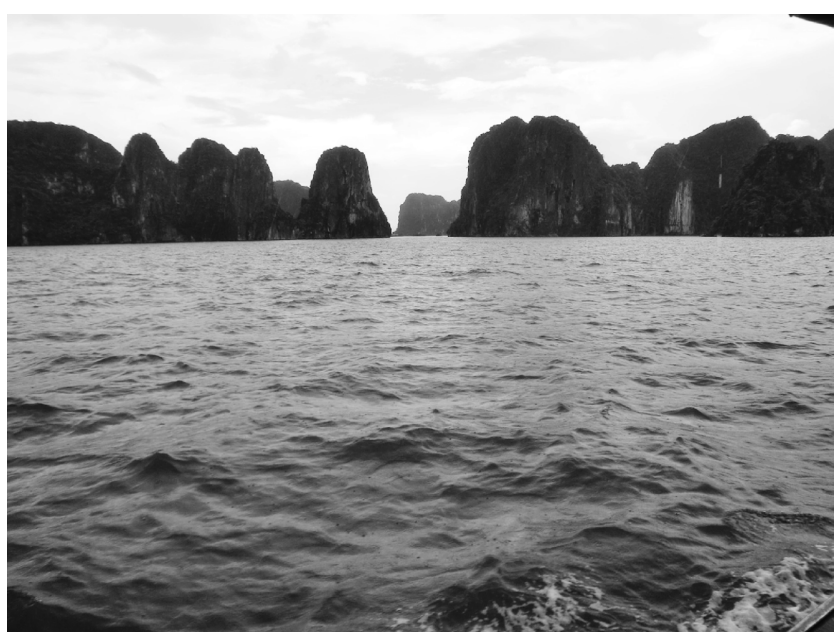

図 2 ハロン湾の無数の島

りた龍の親子が宝玉を吹き出し，それが島となって海から 侵入してくる外敵を防いだという伝説が命名の由来となっ ている. 図 2 にハロン湾の絶景を示す。海から突き出た無 数の島の間を船でクルージングしながら昼食をとった後, ハロン湾にある鍾乳洞を見学した. 自然がつくりだした造 形美が感動的であった. 見学終了後, バスで空港に向かい, 4 日間のスケジュールが無事に終了した。 